\title{
OCCURRENCE OF ENTEROPARASITES IN DAY CARE CENTERS IN BOTUCATU (SÃO PAULO STATE, BRAZIL) WITH EMPHASIS ON Cryptosporidium sp., Giardia duodenalis AND Enterobius vermicularis
}

\author{
Thaís Batista de CARVALHO(1) , Lídia Raquel de CARVALHO(2) \& Luciene Maura MASCARINI(3)
}

\begin{abstract}
SUMMARY
The occurrence of the enteroparasites was verified in 279 children (0 to 6 years) of four municipal day cares of Botucatu/SP. Three samples of each child's feces were collected and processed by the methods of Hoffman-Pons-Janner, Faust and Ritchie and subsequent coloration of the fecal smear by the methods of Auramina-O and Ziehl-Neelsen modified for diagnosis of Cryptosporidium sp. and Graham method for diagnosis of Enterobius vermicularis. Of the analyzed children we verified a prevalence of intestinal parasitism in $53.40 \%$, and the most frequent parasite was Giardia duodenalis $(26.88 \%)$. Significant association was verified among enteroparasitosis, family income, maternal education and age; the lowest enteroparasite frequency occurred in children of families with larger income and higher education. It was observed that $G$. duodenalis is more prevalent in children from 0 to 4 years and E. vermicularis is more frequent in children between three and four years old. The high enteroparasite prevalence in day cares suggests complex structure in its epidemiology, where factors beyond sanitation should be considered.
\end{abstract}

KEYWORDS: Enteroparasites; Day care centers; Children; Epidemiological aspects; Brazil.

\section{INTRODUCTION}

Despite scientific and technological advances over the years, intestinal parasites still constitute a grave public health problem ${ }^{4}$. This situation is characteristic, principally, of developing countries, in which actions to control enteroparasites are made more difficult by financial cost of technical measures (infrastructure) and by lack of educational projects that aim for elucidation of the population ${ }^{17}$. Allied with this are added low socioeconomic and cultural levels and deficient habits of individual hygiene ${ }^{19}$.

In Brazil, the pediatric population has been the group most harmed by high incidences of parasitic infection. This is due to problems emanating from these infections such as chronic diarrhea and malnutrition, which can affect intellectual and physical development of this age group ${ }^{28,30,33}$.

Currently, one of the environments in which children are susceptible to intestinal parasites are nursery schools, which have acquired fundamental importance in the care of preschoolers since women started to increase participation in the labor market ${ }^{10}$.

In nursery schools, the accentuated risk of exposure to enteroparasites is due to characteristics inherent to these establishments including the facility of interpersonal contact (child-child, child- functionary), poorly-trained functionaries and inadequate hygiene conditions inherent in children such as: immaturity of the immune system, the oral phase of exploration, hygiene habits still in formation and constant intimate contact with soil ${ }^{10}$.

By virtue of the harm that intestinal parasites provoke in the development and growth of preschool-aged children, the present study aims to determine prevalences of Cryptosporidium sp., Giardia duodenalis, Enterobius vermicularis and the other enteroparasites in the infantile population attending nursery schools in Botucatu, São Paulo State, to investigate possible associations between occurrence of enteroparasites and the socioeconomic and sanitary conditions of children matriculated in these institutions, and to verify the frequencies of intestinal parasites in employees of these same nursery schools who may serve as the infection source.

\section{MATERIAL AND METHODS}

Area of the study: In the period from July to December of 2002, an epidemiological inquiry was realized with 279 children (ages between 0 and 6 years) and 42 employees from four municipal nursery schools in Botucatu, São Paulo. The municipal district of Botucatu own 17 municipal day cares located in the urban area (outlying and central) and rural area. The four Institutions that participated in the random study were raffled among the day cares of the municipal district, located in an urban zone: Cohab, Vila Ferroviária and Vila dos 


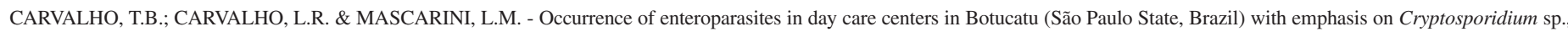
Giardia duodenalis and Enterobius vermicularis. Rev. Inst. Med. trop. S. Paulo, 48(5): 269-273, 2006.

Lavradores and one rural area, the Vitoriana nursery school. All of the children and employees participated in the study.

Collection of epidemiological data: Structured questionnaires were applied to obtain socioeconomic and sanitary data of families of the children and of the nursery-school employee. Variables were analyzed for sex, age, maternal education level, family income, consumption of fruits and raw vegetables, procedures for water consumption, water and sewer services, presence of domestic animals, occurrence of diarrhea and breast-feeding accomplishment. A questionnaire was also applied to directors of the nursery schools in order to characterize each of them and determine aspects of their hygiene, sanitation and diet.

Parasitological examination of feces: Three samples of feces, at three-day intervals between each, were collected from each child and employee. The fecal material was stored in collection flasks containing formalin $10 \%$ and previously identified with the name of the participant in the study. Additionally there was collected fecal material from the perianal region of all the children by the Graham method ${ }^{12}$. The three fecal samples were processed in the Department of Parasitology of the Institute of Biosciences at UNESP-Botucatu where the samples were homogenized, forming a "fecal pool". The following methods were employed for processing of the feces: spontaneous sedimentation in water $^{15}$ and fluctuation centrifuge in zinc sulfate ${ }^{7}$, for determination of helminth eggs and protozoan cysts, sedimentation centrifuge in PBSether $^{29}$ and posterior coloration of the fecal smear by auramine ${ }^{3}$ (screening in immunoflorescence) and Ziehl-Neelsen ${ }^{14}$ modification of visualization of oocysts of Cryptosporidium sp. The Graham method ${ }^{12}$ slides were employed to visualize eggs of E. vermicularis. Infected persons were sent to health clinics near their respective residences for treatment of the parasitosis found. The referenced project was approved by the Committee of Ethics in Research at the School of Medicine at Botucatu, UNESP, with the official registration number 332/99-CEP.

Statistical analysis: From the data obtained were constructed frequency tables of parasites and the calculated prevalence coefficients of parasites found in children and functionaries, and associations realized between occurrence of enteroparasites and some socioeconomic and sanitary variables were analyzed in the study. These associations were verified by the chi-square test, with results considered statistically significant for $p \leq 0.05$.

\section{RESULTS}

In the present inquiry, fecal samples of 279 children (128 female and 151 male) attending one of four municipal nursery schools in Botucatu, São Paulo State, Brazil were analyzed for intestinal parasites. The general coefficient of prevalence of enteroparasitoses for this population was $53.40 \%$, with the species G. duodenalis, Cryptosporidium sp., Blastocystis hominis and E. vermicularis found in the greatest frequency $(26.88 \%, 15.05 \%, 14.34 \%$ and $10.04 \%$, respectively). Only one parasite (monoparasitism) was observed in $57.72 \%$ ( 86 children) and the multiparasitism (two or more parasites) was observed in $42.28 \%$ (63) children. Data from other enteroparasites are specified in Table 1.

From the socioeconomic-sanitary questionnaire answered by those responsible for the children were extracted the following data: $96.06 \%$
Table 1

Prevalence of intestinal parasites among children in four day care centers of Botucatu, São Paulo State $(\mathrm{n}=279), 2002$

\begin{tabular}{lcc}
\hline Parasites & No. infected & $(\%)$ infected \\
\hline Ascaris lumbricoides & 17 & 6.09 \\
Trichuris trichiura & 16 & 5.73 \\
Strongyloides stercoralis & 2 & 0.72 \\
Enterobius vermicularis & 28 & 10.04 \\
Hymenolepis nana & 3 & 1.08 \\
Giardia duodenalis & 75 & 26.88 \\
Blastocystis hominis & 40 & 14.34 \\
Entamoeba coli & 19 & 6.81 \\
Cryptosporidium sp. & 42 & 15.05 \\
Endolimax nana & 6 & 2.15 \\
Positive & 149 & 53.40 \\
One parasite & 86 & 57.72 \\
Two or more parasites & 63 & 42.28 \\
Negative & 130 & 46.60 \\
\hline
\end{tabular}

of the residences had access to running water, $89.25 \%$ possessed a sewer network, and $34.41 \%$ and $44.80 \%$ of children utilized, respectively, tap and filtered water for consumption. $59.50 \%$ of the residences had domestic animals, $89.61 \%$ of the children were fed diets including fruits and raw vegetables, $82.44 \%$ of mothers breastfed their children for at least some days of life and $12.19 \%$ of children researched presented episodes of diarrhea in the days before collection of fecal samples.

Of the 149 children infected with at least one parasite species, $41.61 \%$ corresponded to girls and $58.39 \%$ to boys, although the difference observed between the sexes was not considered significant $(p=0.126)$.

It was verified that the enteroparasitoses varied intensely according to age of the child (Table 2). The parasites Ascaris lumbricoides,

Table 2

Prevalence of intestinal parasites by age (years-old) among children of four day care centers of Botucatu, São Paulo State, in $2002(n=277)^{1}$

\begin{tabular}{|c|c|c|c|c|c|c|}
\hline \multirow[t]{2}{*}{ Parasites } & \multicolumn{2}{|c|}{$\begin{array}{l}(0-2) \\
n=67\end{array}$} & \multicolumn{2}{|c|}{$\begin{array}{c}(3-4) \\
n=135\end{array}$} & \multicolumn{2}{|c|}{$\begin{array}{l}(5-6) \\
n=75\end{array}$} \\
\hline & $\begin{array}{c}\text { No. } \\
\text { infected }\end{array}$ & $\%$ & $\begin{array}{c}\text { No. } \\
\text { infected }\end{array}$ & $\%$ & $\begin{array}{c}\text { No. } \\
\text { infected }\end{array}$ & $\%$ \\
\hline A. lumbricoides ${ }^{\text {a }}$ & 1 & 1.49 & 5 & 3.70 & 11 & 14.66 \\
\hline T. trichiuris $^{\mathbf{b}}$ & 1 & 1.49 & 6 & 4.40 & 9 & 12.0 \\
\hline E. vermicularis ${ }^{\mathbf{c}}$ & 1 & 1.49 & 19 & 14.07 & 8 & 10.66 \\
\hline S. stercoralis* & 0 & 0 & 0 & 0 & 2 & 1.33 \\
\hline H. nana* & 1 & 1.49 & 1 & 1.33 & 1 & 1.33 \\
\hline G. duodenalis ${ }^{\mathrm{d}}$ & 27 & 40.29 & 28 & 20.74 & 19 & 25.33 \\
\hline E. nana $*$ & 1 & 1.49 & 5 & 3.70 & 0 & 0 \\
\hline E. coli $^{\mathbf{e}}$ & 1 & 1.49 & 8 & 5.92 & 10 & 13.33 \\
\hline B. hominis* & 5 & 7.46 & 19 & 14.07 & 16 & 21.30 \\
\hline Cryptosporidium sp.* & 12 & 17.9 & 17 & 12.59 & 13 & 17.3 \\
\hline
\end{tabular}

(a) $\mathrm{p}=0.001$; $^{\text {(b) }} \mathrm{p}=0.018$; $^{\text {(c) }} \mathrm{p}=0.020$; $^{\text {(d) }} \mathrm{p}=0.012$; $^{\text {(e) }} \mathrm{p}=0.017$; $^{*}$ not significant;

${ }^{1}$ two children $=$ without information about age. 


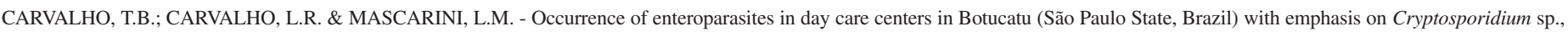
Giardia duodenalis and Enterobius vermicularis. Rev. Inst. Med. trop. S. Paulo, 48(5): 269-273, 2006.

Table 3

Distribution of frequency of intestinal parasites according to four day care centers of Botucatu, São Paulo State, in 2002 (n = 279)

\begin{tabular}{|c|c|c|c|c|}
\hline Parasites & Day care A $(n=62)$ & Day care B $(\mathrm{n}=89)$ & Day care $C(n=85)$ & Day care $D(n=43)$ \\
\hline A. lumbricoides ${ }^{\text {a }}$ & $0.00 \%(0)$ & $0.00 \%(0)$ & $82.35 \%(14)$ & $17.65 \%(3)$ \\
\hline T. trichiura $\mathbf{b}$ & $6.25 \%(1)$ & $6.25 \%(1)$ & $81.25 \%(13)$ & $6.25 \%(1)$ \\
\hline E. vermicularis ${ }^{\mathbf{c}}$ & $10.71 \%(3)$ & $7.14 \%(2)$ & $42.86 \%(12)$ & $39.29 \%(11)$ \\
\hline S. stercoralis * & $0.00 \%(0)$ & $0.00 \%(0)$ & $100.0 \%(2)$ & $0.00 \%(0)$ \\
\hline H. nana * & $0.00 \%(0)$ & $33.3 \%(1)$ & $66.6 \%(2)$ & $0.00 \%(0)$ \\
\hline G. duodenalis ${ }^{\mathbf{d}}$ & $18.67 \%(14)$ & $17.33 \%(13)$ & $48.00 \%(36)$ & $16.00 \%(12)$ \\
\hline E. nana* & $0.00 \%(0)$ & $16.66 \%(1)$ & $16.66 \%(1)$ & $66.6 \%$ \\
\hline E. $\operatorname{coli} *$ & $31.58 \%(6)$ & $5.26 \%(1)$ & $47.37 \%(9)$ & $15.79 \%(3)$ \\
\hline B. hominis ${ }^{\mathrm{e}}$ & $10.00 \%$ & $15.00 \%(6)$ & $57.50 \%(23)$ & $17.50 \%(7)$ \\
\hline Cryptosporidium sp. ${ }^{\mathrm{f}}$ & $2.38 \%(1)$ & $35.71 \%(15)$ & $59.52 \%(25)$ & $2.38 \%(1)$ \\
\hline Total number & $16.78 \%(25)$ & $21.48 \%(32)$ & $43.62 \%(65)$ & $18.12 \%(27)$ \\
\hline
\end{tabular}

Day care A = Cohab; day care B = Vila Lavradores; day care $\mathrm{C}=$ Vitoriana; day care $\mathrm{D}=$ Vila Ferroviária; ${ }^{(\mathrm{a})} \mathrm{p}=0.01 ;{ }^{\text {(b) }} \mathrm{p}=0.001 ;{ }^{\left({ }^{(\mathrm{c})}\right.} \mathrm{p}=0.001 ;{ }^{\left({ }^{(d)}\right)} \mathrm{p}=0.001 ;{ }^{(\mathrm{e})} \mathrm{p}=0.001$;

(f) $\mathrm{p}=0.001 ; *$ not significant; ()$=$ no. infected.

Trichuris trichiura, E. vermicularis, G. duodenalis and Entamoeba coli presented significant association with the age-group variable. The presence of the helminthes A. lumbricoides and T. trichiura and the protozoan $E$. coli increases with age, although the opposite occurs for G. duodenalis, since it presents greater prevalence $(74.33 \%)$ in the younger age groups (0 to 4 years). Yet E. vermicularis presented intermediate behavior, since the category between three and four years was the most affected by this parasite $(67.86 \%)$.

As to distribution of parasites according to the nursery school analyzed (Table 3), it was verified that Vitoriana, located in a rural area, was the one that presented the greatest percentage of infected preschoolers (43.62\% in relation to 149 children positive for some parasite species). The prevalences that should be emphasized for this institution are: $A$. lumbricoides $(82.35 \%)$, T. trichiura $(81.25 \%)$, Cryptosporidium sp. (59.52\%), B. hominis (57.50\%) and G. duodenalis (48\%).

Tables 4 and 5 show that the relation between infection by helminthes and protozoa and the socioeconomic variables (family income or level of maternal education) is intense and linear. Children belonging to the lowest-income stratum (less than one minimum salary) presented greater frequency of parasitic infection than that found in the highest income category (superior to three minimum salaries). The same occurred with maternal education, since parasitic infection in children with illiterate mothers $(80.00 \%)$ is much greater than in those whose mothers had a university education $(26.32 \%)$.

However, it was verified that the occurrence of Cryptosporidium sp. and the variables for diarrhea and domestic animals were not associated in a statistically significant manner. The presence of $G$. duodenalis in children and the variables for maternal nursing and for consumption of fruits and raw vegetables did not present a statistically significant association.

The overall prevalence found in parasitological exams of the 42 nursery-school functionaries was $57.14 \%$, in other words, 24 persons infected and these parasites found were Cryptosporidium sp. (23.81\%), B. hominis $(21.43 \%)$, G. duodenalis $(11.90 \%)$, E. coli $(21.43 \%)$ and Hymenolepis nana $(2.38 \%)$.

\section{Table 4}

Distribution of frequency of enteroparasites according to family income among children of four day care centers of Botucatu, São Paulo State, in 2002 $(\mathrm{n}=266)^{1}$

\begin{tabular}{lcc}
\hline Family income & $\begin{array}{c}\text { No. children } \\
\text { infected }\end{array}$ & $\begin{array}{c}\text { \% children } \\
\text { infected }\end{array}$ \\
\hline$<1 \mathrm{mw}(\mathrm{n}=7)$ & 5 & 71.43 \\
$1-2 \mathrm{mw}(\mathrm{n}=112)$ & 72 & 64.29 \\
$>3 \mathrm{mw}(\mathrm{n}=147)$ & 69 & 46.94 \\
\hline
\end{tabular}

$\mathrm{X}^{2}=8.520 ; \mathrm{p}=0.014 ; \mathrm{mw}=$ minimum wage in Brazil; ${ }^{1} 13$ children $=$ without information about family income.

Table 5

Distribution of frequency of enteroparasites according to degree of maternal education among children of four day care centers of Botucatu, São Paulo State, in $2002(\mathrm{n}=265)^{1}$

\begin{tabular}{lcc}
\hline Degree of maternal education & $\begin{array}{c}\text { No. children } \\
\text { infected }\end{array}$ & $\begin{array}{c}\text { \% children } \\
\text { infected }\end{array}$ \\
\hline Without formal education $(\mathrm{n}=5)$ & 4 & 80.00 \\
First degree $(\mathrm{n}=146)$ & 88 & 60.27 \\
Second Degree $(\mathrm{n}=95)$ & 46 & 48.42 \\
University $(\mathrm{n}=19)$ & 5 & 26.32 \\
\hline
\end{tabular}

$\overline{\mathrm{X}^{2}}=10.725 ; \mathrm{p}=0.013 ;{ }^{1} 14$ children $=$ without information about degree of maternal education.

\section{DISCUSSION}

It is known that the transmission of enteroparasites depends on the presence of infected individuals, sanitation deficiencies and, principally, the socioeconomic and cultural conditions of the population ${ }^{20}$. In this inquiry the truth of this premise can be verified given the elevated prevalence $(53.40 \%)$ observed among children in the nursery schools and due to relevant associations among the presence of parasitism, 


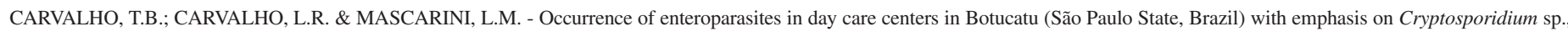
Giardia duodenalis and Enterobius vermicularis. Rev. Inst. Med. trop. S. Paulo, 48(5): 269-273, 2006.

family income and degree of maternal education (the greater the income and level of maternal education, the lower the presence of enteroparasites). The inverse relation among parasitism, level of instruction and family income corroborates earlier findings in preschoolers, which associated the high frequency of parasitic infections with low socioeconomic and cultural level of the population ${ }^{9,17,19}$.

Of the nursery schools studied, Vitoriana (rural area) presented the greatest percentage of enteroparasitoses $(43.62 \%)$. This situation may have occurred on account of the socioeconomic and social profile of this community which presented low family income, poor residential hygiene and at-risk personnel, which also can be attributed to frequent agglomeration that is characteristic of the nursery-school environment. In the same nursery school the same pattern of infection was observed ${ }^{13}$.

The low frequencies of helminthes, especially A. lumbricoides (6.09\%) and T. trichiura $(5.73 \%)$ found in this inquiry, compared to the rates of $13.90 \%-33.00 \%$ (A. lumbricoides) and $3.70 \%-25.00 \%$ (T. trichiura) observed by other authors ${ }^{5,6,13,31}$, may be attributed to improvements in the water supply and in sanitary installations, so that the majority of children researched presented running water and sewer service in their residences. There is a historical tendency toward reduction of these parasites in the State of São Paulo, attributable to improvements in the water and sewer network ${ }^{9,17}$.

Despite low prevalences of helminthes in the nursery schools, the species E. vermicularis was characterized as being the most frequent among the children (10.04\%), especially in those between three and four years of age, which could be due to hygienic habits still in formation in this age group ${ }^{26}$. The rate of $10.04 \%$ agrees with the study realized by SIGULEM et al. ${ }^{31}$ (with $9.00 \%$ positive for E. vermicularis in less than five years). Few studies on the frequency of parasitoses in children search the eggs of E. vermicularis, the Graham method ${ }^{12}$, so that the true prevalence of this helminth can be underestimated in many findings $\mathrm{s}^{6,11,13}$.

The enteroparasite Cryptosporidium sp. in this study, was the second most frequent parasite among the children $(15.05 \%)$, with this prevalence being superior to that observed by other authors ${ }^{2,10,27}$, in as much as the rates of the latter are between $1.10 \%$ and $11.20 \%$. However, in an anterior study ${ }^{21}$ realized in Botucatu, SP, the prevalence of this protozoan was also elevated (38.20\%). The difference observed among the frequencies of Cryptosporidium sp. may occur on account of various factors: methodology in processing of feces, degree of development in each region and characteristics of different populations ${ }^{10}$. Although some studies ${ }^{23,24}$ attribute episodes of diarrhea in developing areas to Cryptosporidium sp., in this inquiry it was not evidenced, as only nine of the 42 positive children were symptomatic. The agglomeration of children, common in nursery schools (person-to-person contact), appears to be the principal potentializing factor for the transmission of Cryptosporidium sp.

In this inquiry, positivity for $G$. duodenalis (26.88\%) compared to the other findings, was shown to be intermediate, given the great differences observed among various studies ${ }^{6,8,10,11,13,32}$.

One possible reason for the discrepancies between these frequencies may be the methodology employed in the processing of feces, since $G$. duodenalis presents intermittent elimination of its cysts ${ }^{25}$. According to a study realized in nursery schools ${ }^{13}$, it was verified that this parasite afflicted with greater frequency children from one to four years of age, which also was observed in this inquiry. The greater prevalence of $G$. duodenalis in this age group may occur due to the acquisition of mobility as to formation of hygiene habits and absence of immunity to reinfection. Although some studies ${ }^{16,18,22}$ attribute this to premature weaning (nursing as an important factor in resistance to and prevention of giardiasis) and to elevated ingestion of raw vegetables ${ }^{1}$, the increased frequency of $G$. duodenalis among the children, this was not observed in this study, since no significant associations were found among these variables. As it is common to find cysts of $G$. duodenalis on the fingers and under the fingernails, it can be concluded that in nursery schools the principal form of transmission of this parasite among the children points to contact.

By virtue of the elevated parasitism found in children of the nursery schools in Botucatu, it is concluded that both these environments and the cultural and socioeconomic-sanitary patterns are, from an epidemiological point of view, enabling factors in early acquisition of parasitic agents by preschool-aged children.

\section{RESUMO}

\section{Ocorrência de enteroparasitas em creches de Botucatu (Estado de São Paulo, Brasil) com ênfase em Cryptosporidium sp., Giardia duodenalis e Enterobius vermicularis}

Verificou-se a prevalência dos enteroparasitas em 279 crianças (0 a 6 anos) de quatro creches municipais de Botucatu/SP. Foram coletadas três amostras de fezes de cada criança e processadas pelos métodos Hoffman, Faust e Ritchie e posterior coloração do esfregaço fecal pelos métodos de Auramina-O e Ziehl-Neelsen modificado para diagnóstico de Cryptosporidium sp. e método da fita gomada para diagnóstico de Enterobius vermicularis. Das crianças analisadas apresentaram-se parasitadas $53.40 \%$, sendo que o parasita mais freqüente foi Giardia duodenalis $(26.88 \%)$. Verificou-se associação significativa entre enteroparasitose, renda familiar, escolaridade materna e idade; quanto maior a renda e o grau escolar, menor a frequiência de enteroparasitas. Observou-se que $G$. duodenalis é mais prevalente em crianças de 0 a 4 anos e E. vermicularis em crianças entre três e quatro anos de idade. A elevada prevalência de enteroparasitas em creches sugere estrutura complexa em sua epidemiologia, onde fatores além do saneamento devem ser considerados.

\section{ACKNOWLEDGMENTS}

We are grateful to the professors and functionaries of the Department of Parasitology, especially Marcia Maria Fattori and the trainee Viviane Mattos Pasquotto, for their kind help in the processing of feces samples and workers at the municipal nursery schools included in this study.

\section{REFERENCES}

1. CARDoso, G.S.; SANTANA, A.D.C. \& AGUIAR, C.P. - Prevalência e aspectos epidemiológicos da giardíase em creches no município de Aracajú, SE, Brasil. Rev. Soc. bras. Med. trop., 28: 25-31, 1995. 
2. CHACIN-BONILLA, L.; BONILLA, M.C.; SOTO-TORRES, L. et al. - Cryptosporidium parvum in children with diarrhea in Zulia State, Venezuela. Amer. J. trop. Med. Hyg., 56: 365-369, 1997.

3. CASEMORE, D.P. - ACP Broadsheet 128: June 1991. Laboratory methods for diagnosing cryptosporidiosis. J. clin. Path., 44: 445-451, 1991.

4. CHAN, M.S. - The global burden of intestinal nematode infections: "fifty years". Parasit. today, 13: 438-443, 1997.

5. DEVERA, R.A.; PUNOS, G.N.; VELÁSQUEZ, V.J.; CATANESE, J.A.N. \& MENESES, R.G. - Prevalencia de infección por Blastocystis hominis en escolares de Ciudad Bolívar, Venezuela. Bol. chil. Parasit., 52: 77-81, 1997.

6. DIAS, M.T. \& GRANDINI, A.A. - Prevalência e aspectos epidemiológicos de enteroparasitoses na população de São José da Bela Vista, SP. Rev. Soc. bras. Med. trop., 32: 63-65, 1999.

7. FAUST, E.C.; SAWITZ, W.; TOBIC, J. et al. - Comparative efficiency of various technics for the diagnosis of Protozoa and helminths in feces. J. Parasit., 25: 241-262, 1938.

8. FERREIRA, C.B. \& MARÇAL Jr., O. - Enteroparasitoses em escolares do distrito de Martinésia, Uberlândia, MG: um estudo piloto. Rev. Soc. bras. Med. trop., 30: 373-377, 1997.

9. FERREIRA, M.U.; FERREIRA, C.S. \& MONTEIRO, C.A. - Tendência secular das parasitoses intestinais na infância na cidade de São Paulo. Rev. Saúde públ. (S.Paulo), 34(supl.): 73-82, 2000

10. FRANCO, R.M.B. \& CORDEIRO N.S. - Giardiose e criptosporidiose em creches no município de Campinas, SP. Rev. Soc. bras. Med. trop., 29: 585-591, 1996.

11. GIRALDI, N.; VIDOTTO, O.; NAVARRO, I.T. \& GARCIA J.L. - Enteroparasites prevalence among daycare and elementary school children of municipal schools, Rolândia, PR, Brazil. Rev. Soc. bras. Med. trop., 34: 385-387, 2001.

12. GRAHAM, C.F. - A device for the diagnosis of Enterobius vermicularis. Amer. J. trop. Med., 21: 159-161, 1941.

13. GUIMARÃES, S. \& SOGAYAR, M.I.L. - Occurrence of Giardia lamblia in children of municipal day-care centers from Botucatu, São Paulo State, Brazil. Rev. Inst. Med. trop. S. Paulo, 37: 501-506, 1995.

14. HENRIKSEN, S.A. \& POHLENZ, J.F.L. - Staining of cryptosporidia by a modified Ziehl-Neelsen technique. Acta vet. scand., 22: 594-596, 1981.

15. HOFFMAN, W.A.; PONS, J.A. \& JANER, J.L. - The sedimentation concentration method in schistosomiasis mansoni. Puerto Rico J. publ. Hlth, 9: 281-298, 1934.

16. LÓPEZ, F.R.D.; MONTERO, M.; GONZÁLEZ, J.D. \& ÁLVAREZ, M.A.G. - Factores de riesgo de giardiasis en niños de 0 a 6 años. Rev. cuba. Med. Gen. Integr., 13: 227-231, 1997.

17. LUDWIG, K.M.; FREI, F; ALVARES, F.F. \& RIBEIRO-PAES, J.T. - Correlação entre condições de saneamento básico e parasitoses intestinais na população de Assis, Estado de São Paulo. Rev. Soc. bras. Med. trop., 32: 547-555, 1999.

18. MACEDO, L.M.C. \& REY, L. - Aleitamento e parasitismo intestinal materno-infantil. Rev. Soc. bras. Med. trop., 33: 371-375, 2000
19. MACHADO, R.C.; MARCARI, E.L., CRISTANTE, S.F.V. \& CARARETO, C.M.A. Giardíase e helmintíases em crianças de creches e escolas de $1^{\circ}$ e $2^{\circ}$ graus (públicas e privadas) da cidade de Mirassol (SP, Brasil). Rev. Soc. bras. Med. trop., 32: 697704, 1999.

20. MARZOCHI, M.C.A. \& CARVALHEIRO, J.R. - Estudos dos fatores envolvidos na disseminação dos enteroparasitas. Distribuição de algumas enteroparasitoses em dois grupos populacionais da cidade de Ribeirão Preto, São Paulo, Brasil. Rev. Inst. Med. trop. S. Paulo, 20: 31-35, 1978.

21. MASCARINI, L.M. \& YOSHIDA, E.L.A. - Prevalência de parasitas intestinais com ênfase em Cryptosporidium sp. em creche municipal de Botucatu/SP. In: CONGRESSO BRASILEIRO DE PARASITOLOGIA, 16., São Paulo, 1999. Anais. p. 176.

22. MORROW, A.L.; REVES, R.R.; WEST, M.S. et al. - Protection against infection with Giardia lamblia by breast-feeding in a cohort of Mexican infants. J. Pediat., 121 363-370, 1992.

23. NEWMAN, R.D.; SEARS, C.L.; MOORE, S.R. et al. - Longitudinal study of Cryptosporidium infection in children in northeastern Brazil. J. infect. Dis., 180: 167-175, 1999.

24. NEWMAN, R.D.; ZU, S.X.; WUHIB, T. et al. - Household epidemiology of Cryptosporidium parvum infection in an urban community in Northeast Brazil. Ann. intern Med., 120: 500-505, 1994.

25. NEVES, D.P.; MELO, A.L.; LINARDE, P.M. \& ALMEIDA, R.W.V.- Parasitologia humana. 11. ed. São Paulo, Editora Atheneu, 2005.

26. NÚNEZ, F.A.; HERNÁNDEZ, M. \& FINLAY, C.M. - A longitudinal study of enterobiasis in three day care centers of Havana city. Rev. Inst. Med. trop. S. Paulo, 38: 129132,1996

27. OSHIRO, E.T.; DORVAL, M.E.C.; NUNES, V.L.B.; SILVA, M.A.A. \& SAID L.A.M. Prevalência de Cryptosporidium parvum em crianças abaixo de 5 anos, residentes na zona urbana de Campo Grande, MS, Brasil, 1996. Rev. Soc. bras. Med. trop. 33: $277-280,2000$

28. PEDRAZZANI, E.S.; MELLO, D.A.; PRIPAS, S. et al. - Helmintoses intestinais. II Prevalência e correlação com renda, tamanho da família, anemia e estado nutricional Rev. Saúde públ. (S. Paulo), 22: 384-389, 1988.

29. RITCHIE, L.S. - An ether sedimentation technique for routine stool examination. Bull. U.S. Army med. Dept., 8: 326, 1948

30. SALATA, E.; CORREAA, F.M.A.; SOGAYAR, R.; SOGAYAR, M.I.L. \& BARBOSA, M.A. - Inquérito parasitológico na Cecap, Distrito sede de Botucatu, Estado de São Paulo, Brasil. Rev. Saúde públ. (S. Paulo), 6: 385-392, 1972

31. SIGULEM, D.M.; TUDISCO, E.S.; PAIVA, E.R. \& GUERRA, C.C.C. - Anemia nutricional e parasitose intestinal em menores de 5 anos. Rev. paul. Med., 103: 308 $312,1985$.

32. TORRES, D.M.A.G.V.; CHIEFFI, P.P.; COSTA, W.A. \& KUDZIELICS, E. - Giardíase em creches mantidas pela prefeitura do município de São Paulo, 1982/1983. Rev. Inst. Med. trop. S. Paulo, 33: 137-142, 1991

33. VINHA, C. \& MARTINS, M.R.S. - Parasitoses intestinais entre escolares. J. Pediat. (Rio de J.), 50: 79-84, 1981

Received: 21 December 2005

Accepted: 11 May 2006 